\title{
Modelling and Monitoring Urban Landscape Dynamics over Haridwar, India
}

\author{
Nitin Malik \\ Project Associate \\ Department of Civil \\ Engineering \\ Geomatics Department, \\ IIT-Roorkee, Roorkee
}

\author{
Sakshi Gothi \\ Software Developer \\ Department of Civil \\ Engineering \\ Geomatics Department, \\ IIT-Roorkee, Roorkee
}

\author{
Ritu Saini \\ Project Associate \\ Department of Civil \\ Engineering \\ Geomatics Department, \\ IIT-Roorkee, Roorkee
}

\author{
Pradeep Aswal \\ Project Assistant \\ Department of Civil \\ Engineering \\ Geomatics Department, \\ IIT-Roorkee, Roorkee
}

\begin{abstract}
Rampant urbanization brings opportunities for new infrastructural developments, however, it also has brought serious losses of vegetation land, forest land and water resources. The modelling and projecting of land use pattern is essential to document the urban profile of the city and assessment of consequent environmental impacts. Current study aims to highlight the impact of rapidly urbanizing Haridwar city not only inside the boundaries of the city but also its neighboring rural and semi urban areas. In the first part of the paper, one of the most popular supervised classification algorithm (maximum likelihood) is implemented to quantify the human inference in the city. In the second part the impact is calculated by executing an Urban Landscape Dynamics tool. In order to temporally access the impact of urbanizing, openly available land sat satellite images are used for the year 2008 and 2016.
\end{abstract}

\section{Keywords}

Remote Sensing, GIS, Land Use Land Cover, Urban Growth Modeling, Urban Landscape Dynamics

\section{INTRODUCTION}

Land is one of the main natural resource for supporting the life over planet earth. The land and land cover changes are equally important elements of the larger problem of global and regional environmental changes. Remote sensing technology and satellite data are very helpful for the detection of changes in land uselland cover between 2008-2016. The increasing urban population pressures are putting tremendous pressure on the land use \& land cover of Haridwar City. The expansion of agriculture land can also be attributed to increasing demand to feed the growing population. The decline in the area of the scrub land is due its conversion to arable land. The increase in the built up area is because of increasing demand for institutional and residential space for capital level establishments. The water body has shown little change in area due to encroachment slum dwellers and land developers.

Urbanization is a continuous process and the spatial growth pattern is the manifestation to this evolving phenomenon. The process of urbanization has gained momentum in the last few decades due to increased economic opportunities in urban areas driving population towards urban centers (Ramachandra, Aithal and Sowmyashree, 2014). The urbanized population in India shall see rising trends and by $2030,40 \%$ of the population will be urban (McKinsey \& Company, 2010, Aswal et al., 2018). The role of urbanization is not only seen as an asset to a city's development pattern, but it can rather prove fatal and haphazard. While urbanization remains dramatic in nature, it has its major role to play in developing nation like India (Taubenbock, et al., 2008, Tiwari et al., 2018a). Growth has huge implications, demands infrastructure development, and improved amenities, and hence, there is a grave need to explore areas of concern with the help of drivers of growth specific to each city and accordingly prioritize the development scenario.

Urbanization has been described in terms of its patterns (land use patterns (Thapa and Murayama 2009; Tian et al. 2011)), process (extension of urbanized areas (Xiao et al. 2006)), causes (changing land use practices $\mathrm{Li}$ and Yeh (2004) and their consequences (Galster et al. 2001). Since urbanization is a name for many conditions, thus defining it becomes very difficult (Bhatta et al. 2010). Monitoring of urban growth is highly imperative to ensure a more sustainable existence of human society. Urban expansion impacts environment in more than one ways. For example, creating social segregation (Azocar et al. 2007, Tiwari and Jain, 2014), fragmentation of natural landscapes ( $\mathrm{Su}$ et al. 2010), changing ecology (Nilsson et al. 2003) and biodiversity of the region (Savard et al. 2000; Hasse and Lathrop 2003; Blair 2004), depleting natural resources (Ghosh 2007) and altering hydrology (Nilsson et al. 2003, Carlson 2004) and air quality in the area (Zhang et al. 2004). Urbanization is considered one of the most dynamic and irreversible land use change (Owen et al. 1998) that is massively occurring across the globe (Brockerhoff 2000). This is true in developing countries (Cohen 2006, Tiwari et al 2018b).

In order to concentrate on urbanization and changing pattern of land use, current study is conducted for the Study area covering the areas of Haridwar, witnessed maximum urbanization. Urban landscape dynamics is computed and changing rural and sub urban areas are marked in the focused zone.

\section{STUDY AREA}

Haridwar is one of the district of uttarakhand in India, The holiest place to Hindus, located on the banks of River Ganga with the geographical coordinates $29.945^{\circ}$ North and $78.163^{\circ}$ East. It is situated on the Northern side of India. According to Indian geographical studies its toposheet No.53K4 and its UTM zone is $44 \mathrm{~N}$ (WGS 1984). The Height of haridwar according to Mean Sea level (M.S.L) is $314 \mathrm{~m}$. The total area of Haridwar is $12.3 \mathrm{~km} 2$. The River Ganga is flowing through Haridwar from its source at Gaumukh. At the edge of the Gangotri Glacier, Haridwar presents a kaleidoscope of Indian culture and development.

The city has a population of Approx. 2, 00,000 and about 8 million tourists visit Haridwar on an annual average basis. Today, the city is developing, with the fast developing industrial estate of State Industrial Development Corporation of Uttarakhand (SIDCUL) and Bharat Heavy Electricals Limited (BHEL). 


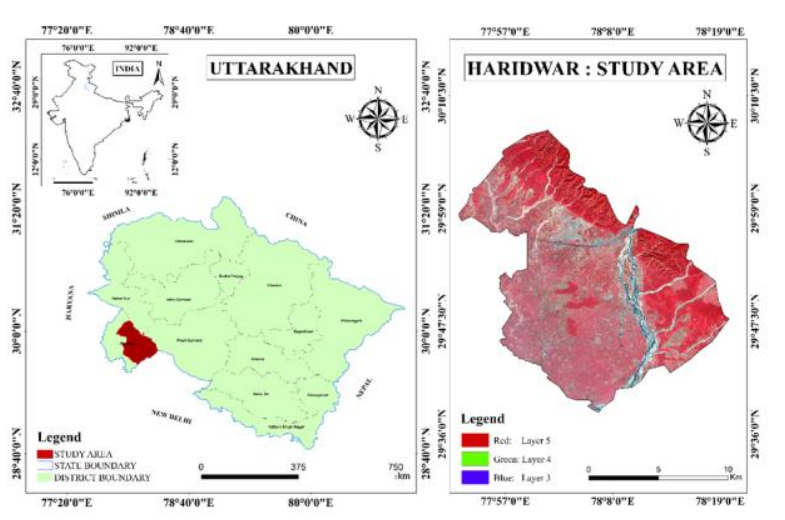

Figure 1. Study Area map of Haridwar

\section{DATA USED}

Multi Spectral satellite imagery of Landsat-5 (ETM+) and Landsat-8 (OLI/TIRS) satellite has been used as primary dataset. The detail specifications of both the images are presented in Table 1. Both the images are downloaded from United States Geological Survey (USGS) Earth Explorer web portal (http://earthexplorer.usgs.gov).

Table 1. Specifications of Landsat 5 and Landsat 8 satellite dataset

\begin{tabular}{|c|c|c|c|c|c|}
\hline $\begin{array}{c}\text { Satellit } \\
\text { e }\end{array}$ & Sensor & $\begin{array}{c}\text { Pat } \\
\text { h }\end{array}$ & $\begin{array}{c}\text { Ro } \\
\mathbf{w}\end{array}$ & $\begin{array}{c}\text { Acquisitio } \\
\text { n Date }\end{array}$ & $\begin{array}{c}\text { Resolution( } \\
\text { m) }\end{array}$ \\
\hline $\begin{array}{c}\text { Lands } \\
\text { at 5 }\end{array}$ & $\begin{array}{c}\text { MSS/T } \\
\text { M }\end{array}$ & 146 & 39 & $\begin{array}{c}23-11- \\
2008\end{array}$ & $30 / 100$ \\
\hline $\begin{array}{c}\text { Lands } \\
\text { at 8 }\end{array}$ & $\begin{array}{c}\text { OLI/TIR } \\
\mathrm{S}\end{array}$ & 146 & 39 & $\begin{array}{c}13-11- \\
2016\end{array}$ & $30 / 100$ \\
\hline
\end{tabular}

\section{URBAN LANDSCAPE DYNAMICS}

Urban Landscape Analysis Tool (ULAT) is used to classify developed areas of different densities to identify undeveloped lands that are likely to be degraded by close proximity to development. This tool is executed in ArcGIS environment.

ULD Tool is not available in the tool bar of ArcGIS, so we have to download the tool and ADD in ArcTool Box after we use Raster Image that contains the land covers data. Layers should be specified in chronological order. Land cover maps should contain the following 3 classes: Output workspace Location of output data other, water and urban. It evaluates results in seven classes shown in the table 2, in the form of Urban built-up area, Suburban built-up area, Rural built-up area, Urbanized open land, Captured open land, Rural open land and Water.

Table 2. Urban classes and their selection criteria

\begin{tabular}{|c|c|c|c|}
\hline $\begin{array}{l}\text { S. } \\
\text { No. }\end{array}$ & Class & $\begin{array}{c}\text { Urbaneness } \\
\text { (U) }\end{array}$ & $\begin{array}{c}\text { Feature } \\
\text { Type }\end{array}$ \\
\hline 1 & $\begin{array}{c}\text { Urban built- } \\
\text { up area }\end{array}$ & $\mathrm{U}>=50 \%$ & Built-up \\
\hline 2 & $\begin{array}{l}\text { Suburban } \\
\text { built-up area }\end{array}$ & $10 \%=<U<50 \%$ & Built-up \\
\hline 3 & $\begin{array}{c}\text { Rural built- } \\
\text { up area }\end{array}$ & $\mathrm{U}<10 \%$ & Built-up \\
\hline 4 & $\begin{array}{l}\text { Urbanized } \\
\text { open land }\end{array}$ & $U>=50 \%$ & Open Land \\
\hline 5 & $\begin{array}{l}\text { Captured } \\
\text { open land }\end{array}$ & $\mathrm{U}<200 \mathrm{Ha}$ & Open Land \\
\hline
\end{tabular}

\begin{tabular}{|c|c|c|c|}
\hline 6 & $\begin{array}{c}\text { Rural open } \\
\text { land }\end{array}$ & - & Open Land \\
\hline 7 & Water & - & $\begin{array}{c}\text { Remain } \\
\text { Same }\end{array}$ \\
\hline
\end{tabular}

\section{METHODOLOGY}

The methodology used for the selected study area uses dataset comprising of satellite imagery of Landsat-5 and Landsat-7 for the year of $2008 \&$ 2016. Both the satellite images were downloaded, and used for image pre-processing and cropped with the boundary of the study area using ERDAS Imagine Software. The flow chart for the methodology is presented in the figure. It is one of the fundamental information required for studies involving environmental monitoring, natural resource management, or even science based-policy making. The prime step of this methodology is mapping of LULC using knowledge based-classification techniques. Since the objective of this study is to study the impact of built-up areas on other land use and land cover categories. Three major land covers mapped are; built-up, water and others. After that we use ULA Tool. ULA stands for Urban Landscape Analysis and it is used for quantification of dynamics of urban expansion. The tool is developed by Centre for Land use Education and Research (CLEAR), University of Connecticut. It identifies and classifies the developed lands of built-up density levels, non-developed areas, and developed lands that are prone to degradation. Based on urbaneness and edge disturbance zone, we mapped Urban Footprint (UF), Urbanized Area (UA) and New Development (ND) lands. ULA determines areas where developed areas entrench on open lands and thus have discrepant impacts on open land. The urbanized area identifies three levels of spatial density in the built-up area. Built-up pixels in areas with lower spatial densities affect a greater amount of open land than builtup pixels in areas of high spatial density. The urbanized open land occurs in areas with high spatial density and is likely to be heavily impacted by development. Captured open land patches are degraded by isolation from other open areas.

Land use and land cover mapping are of great significance in land management and land planning activities. It contributes significantly to increasing land use patterns and biodiversity loss, and is a major factor in sustainable development and human responses to global change. To work out the land use land cover classification, supervised classification method with maximum likelihood algorithm was applied in the ERDAS Imagine Software. Maximum likelihood algorithm (MLC) is one of the most popular supervised classification methods used with remote sensing image data. This method is based on the probability that a pixel belongs to a particular class.

Table 3. Area statistics for different land use land cover class in 2008 and 2016

\begin{tabular}{|c|c|c|c|c|c|}
\hline $\begin{array}{c}\text { Yea } \\
\mathbf{r}\end{array}$ & $\begin{array}{c}\text { Urban } \\
\text { Area } \\
\text { (sq.Km. } \\
\text { ) }\end{array}$ & $\begin{array}{c}\text { Forest } \\
\text { Area } \\
\text { (sq.Km. } \\
\text { ) }\end{array}$ & $\begin{array}{c}\text { Vegetatio } \\
\text { n Area } \\
\text { (sq.Km.) }\end{array}$ & $\begin{array}{c}\text { Barren } \\
\text { land } \\
\text { Area } \\
\text { (sq.Km. } \\
\text { ) }\end{array}$ & $\begin{array}{c}\text { Water } \\
\text { Area } \\
\text { (sq.Km. } \\
\text { ) }\end{array}$ \\
\hline 2008 & $\begin{array}{c}167.474 \\
7\end{array}$ & $\begin{array}{c}334.751 \\
4\end{array}$ & 365.6079 & $\begin{array}{c}324.659 \\
7\end{array}$ & 14.1948 \\
\hline 2016 & $\begin{array}{c}216.574 \\
2\end{array}$ & 261.801 & 381.3993 & $\begin{array}{c}330.406 \\
2\end{array}$ & 16.4997 \\
\hline
\end{tabular}




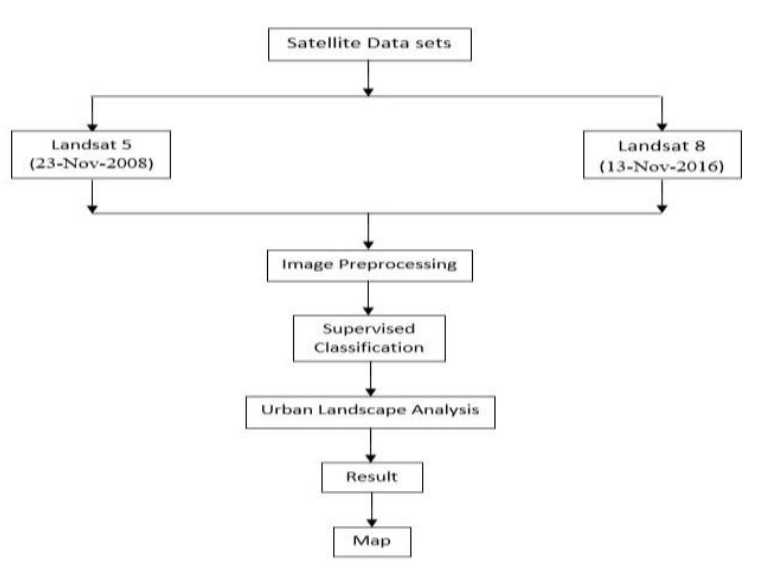

Figure 2. Flow Diagram Explaining Methodology

\section{RESULT AND DISCUSSION}

Land use land cover classification supervised classification method with maximum likelihood algorithm was applied in the ERDAS Imagine Software. Image classification resulted into five land use land cover classes namely, Urban, Forest, Vegetation, Water, and Barren land overall, Vegetation is high in the south region and Forest is high in the northeastern region of the study area. Land use land cover map for both the year are presented in the figure 3. Land use land cover mapping of Haridwar for two times indicates a continuously increasing in built-up areas that comprises of urban, suburban and rural builtup. It is observed that the urban area which was 167.47 square $\mathrm{Km}$ in 2008 is increased up to 216.57 square $\mathrm{Km}$ in 2016. Water, Vegetation and Barren land area are 14.19 square $\mathrm{Km}$, 365.60 square $\mathrm{Km}$ and 324.65 square $\mathrm{Km}$ respectively in 2008 are also increased up to 16.49 square $\mathrm{Km}, 381.39$ square $\mathrm{Km}$ and 330.40 square $\mathrm{Km}$ respectively in 2016 . Whereas the Forest area was 334.75 square $\mathrm{Km}$ in 2008 is decreased up to 261.80 square $\mathrm{Km}$ in 2016. Table 3 shows different statistics of the urban area for both the year. Urban landscape dynamic is also analyzed to see impacts of different levels of urbanization. Seven classes were mapped for urbanized area; urban built-up, suburban builtup, rural built-up, water, captured open land, rural open land and urbanized open land (figure 4). Urban built-up, suburban builtup, urbanized open land, captured open land and water area are 50.49 ha, 15177.42 ha, 37.62 ha, 1234.35 ha, and 14.19 ha respectively in 2008 are increased up to 2204.37 ha, 18273.87 ha, 45669.15 ha, 5571.90 ha and 16.49 ha respectively in 2016 . Whereas the rural built-up and rural open land area are 1515.51 ha and 101135.07 ha respectively in 2008 is decreased up to 1038.96 ha and 45436.68 ha in 2016 respectively. Table 4 shows the ULD area for both the years.
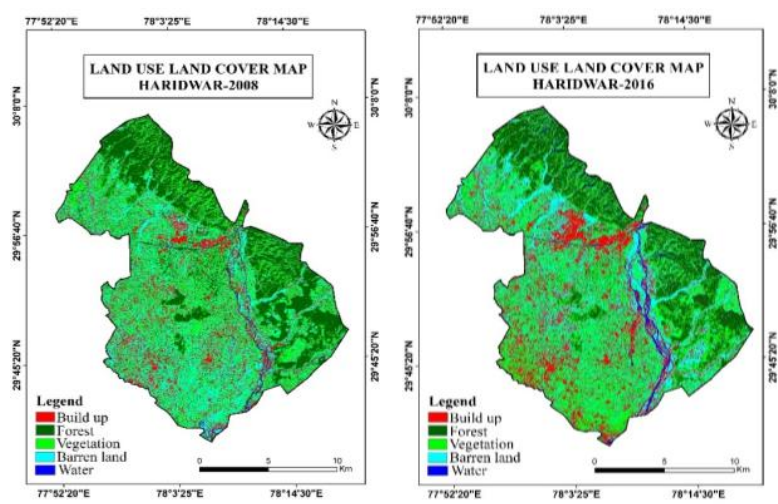

Figure 3. Land use land cover map for 2008 and 2016

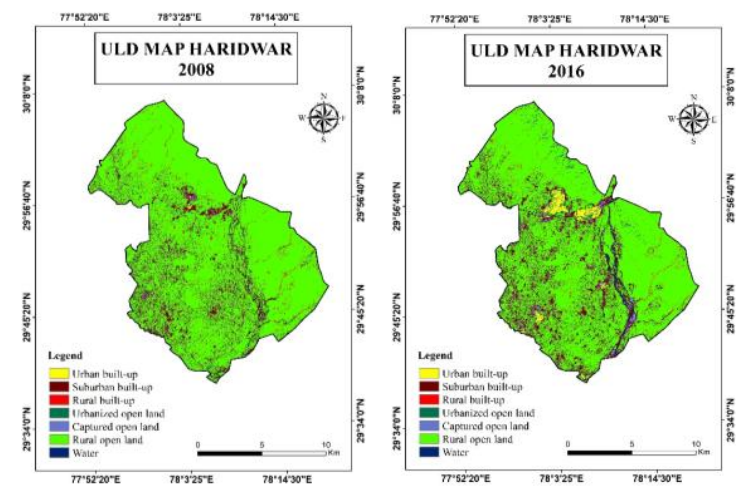

Figure 4. Urban landscape Dynamics for the year 2008 and 2016

Table 4. Urban Landscape Dynamics for the year 2008 and 2016

\begin{tabular}{|c|c|c|}
\hline Year & $\mathbf{2 0 0 8}$ & $\mathbf{2 0 1 6}$ \\
\hline Urban built-up Area (ha) & 50.49 & 2204.37 \\
\hline Suburban built-up Area (ha) & 15177.42 & 18273.87 \\
\hline Rural built-up Area (ha) & 1515.51 & 1038.96 \\
\hline $\begin{array}{c}\text { Urbanized open land Area } \\
\text { (ha) }\end{array}$ & 37.62 & 45669.15 \\
\hline $\begin{array}{c}\text { Captured open land Area } \\
\text { (ha) }\end{array}$ & 1234.35 & 5571.9 \\
\hline Rural open land Area (ha) & 101135.07 & 45436.68 \\
\hline Water Area (ha) & 14.1948 & 16.4997 \\
\hline \multicolumn{2}{|c|}{} \\
\hline
\end{tabular}

\section{CONCLUSION}

The standard image processing techniques such as, image extraction, rectification, restoration, and classification were applied in the current study. Population growth and built-up area are the rate of development of land in haridwar city, is outstripping the rate of population growth. This implies that the land is consumed at excessive rates and probably in unnecessary amounts as well. This means that the per capita consumption of land has increased exceptionally over three decades. The per capita land consumption refers to utilization of all lands for development initiatives like the commercial, industrial, educational, and recreational establishments along with the residential establishments per person. Since most of the initiatives pave way for creation of jobs and subsequently help in earning livelihood, the development of land is seen as a direct consequence of a region's economic development and hence one can conclude that the per capita land consumption is inclusive of all the associated land development. Most of the indices are correlated among themselves, because there are only few primary measurements that can be made from patches (patch type, area, edge, and neighbour type), and all metrics are then derived from these primary measures It was suggested that the development of land value was not accompanied by the development of socio-economic level of the community, causing inefficient and effective land use. In addition, the formal juridical provisions concerning the regulation, control and supervision of the land are still not solid. Therefore some parts of urban land are used and overused, which are occupied by a large group of urbanites. Some of the urban land has been used formally and not optimally, while in some other areas have not been utilized. 


\section{REFERENCES}

[1] Aswal, P., Saini R., and Ansari M. T., 2018. Spatio Temporal Monitoring of Urban Sprawl using GIS and Remote Sensing Technique. International Journal of Computer Applications 182(27):11-24, November 2018.

[2] Azócar, G., Romero, H., Sanhueza, R., Vega, C., Aguayo, M. and Muñoz, M.D., 2007. Urbanization patterns and their impacts on social restructuring of urban space in Chilean mid-cities: The case of Los Angeles, Central Chile. Land Use Policy, 24(1), pp.199-211.

[3] Bhatta, B., 2010. Causes and consequences of urban growth and sprawl. In Analysis of urban growth and sprawl from remote sensing data (pp. 17-36). Springer, Berlin, Heidelberg.

[4] Blair, R., 2004. The effects of urban sprawl on birds at multiple levels of biological organization. Ecology and Society, 9(5).

[5] Brockerhoff, M., 2000. An urbanizing world. Population Reference Bureau.

[6] Carlson, T.N., 2004. Analysis and Prediction of Surface Runoff in an Urbanizing Watershed Using Satellite Imagery 1. JAWRA Journal of the American Water Resources Association, 40(4), pp.1087-1098.

[7] Cohen, B., 2006. Urbanization in developing countries: Current trends, future projections, and key challenges for sustainability. Technology in society, 28(1-2), pp.63-80.

[8] Galster, G., Hanson, R., Ratcliffe, M.R., Wolman, H., Coleman, S. and Freihage, J., 2001. Wrestling sprawl to the ground: defining and measuring an elusive concept. Housing policy debate, 12(4), pp.681-717.

[9] Ghosh, P., 2007. Urbanization-A potential threat to the fragile Himalayan environment. Current Science, 93(2), pp.126-127.

[10] Hasse, J.E. and Lathrop, R.G., 2003. Land resource impact indicators of urban sprawl. Applied geography, 23(2-3), pp.159-175.

[11] Koller, T., Goedhart, M., Wessels, D. and Copeland, T.E., 1946. McKinsey and Company (2010). Valuation: Measuring and managing the value of companies, 5 .

[12] Li, X. and Yeh, A.G.O., 2004. Analyzing spatial restructuring of land use patterns in a fast growing region using remote sensing and GIS. Landscape and Urban planning, 69(4), pp.335-354.

[13] Nilsson, C., Pizzuto, J.E., Moglen, G.E., Palmer, M.A., Stanley, E.H., Bockstael, N.E. and Thompson, L.C., 2003. Ecological forecasting and the urbanization of stream ecosystems: challenges for economists, hydrologists, geomorphologists, and ecologists. Ecosystems, 6(7), pp.659-674.

[14] Owen, T.W., Carlson, T.N. and Gillies, R.R., 1998. An assessment of satellite remotely sensed land covers parameters in quantitatively describing the climatic effect of urbanization. International journal of remote sensing, 19(9), pp.1663-1681.

[15] Ramachandra, T.V., Bharath, H.A., Vinay, S., Venugopal, K.R. and Joshi, N.V., 2015. Geospatial scenario based modelling of urban revolution in five major cities in India. Proceedings of IISc-ISRO-STC, Indian Institute of Science, Bangalore, India.

[16] Savard, J.P.L., Clergeau, P. and Mennechez, G., 2000 Biodiversity concepts and urban ecosystems. Landscape and urban planning, 48(3-4), pp.131-142.

[17] Su, S., et al. (2012) 'Characterizing landscape pattern and ecosystem service value changes for urbanization impacts at an eco-regional scale', Applied Geography, 34, pp.295305.

[18] Taubenböck, H., et al. (2008) 'Urban structure analysis of mega city Mexico City using multisensoral remote sensing data', In Remote Sensing for Environmental Monitoring, GIS Applications, and Geology VIII (Vol. 7110, p. 71100E),International Society for Optics and Photonics.

[19] Thapa, R.B. and Murayama, Y., (2009) 'Examining spatiotemporal urbanization patterns in Kathmandu Valley, Nepal: Remote sensing and spatial metrics approaches', Remote Sensing, 1(3), pp.534-556.

[20] Tian, G., et al. (2011) 'The urban growth, size distribution and spatio-temporal dynamic pattern of the Yangtze River Delta megalopolitan region, China', Ecological Modelling, 222(3), pp.865-878.

[21] Tiwari, A. Tyagi, D. Sharma, S.K. Suresh, Jain, K. 2018. Multi-criteria Decision Analysis for Identifying Potential Sites for Future Urban Development in Haridwar, India

[22] Tiwari, A. and Jain, K., 2014. GIS Steering smart future for smart Indian cities. International Journal of Scientific and Research Publications, 4(8), pp.442-446.

[23] Tiwari, A., Suresh, M., Jain, K., Shoab, M., Dixit, A. and Pandey, A., 2018. Urban Landscape Dynamics for Quantifying the Changing Pattern of Urbanisation in Delhi. Journal of Rural Development, 37(2), pp.399-412.

[24] Xiao, J., et al. (2006) 'Evaluating urban expansion and land use change in Shijiazhuang, China, by using GIS and remote sensing', Landscape and urban planning, 75(1-2), pp.69-80.

[25] Zhang, X., et al. (2004) 'The footprint of urban climates on vegetation phenology', Geophysical Research Letters, $31(12)$. 